\title{
MPPT INCREMENTAL CONDUCTANCE TECHNIQUE FOR PV SYSTEMS
}

\author{
Ms Rucha P.Kawde (Student) \\ Department of EE \\ Priyadarshini College of Engg., \\ Nagpur, Maharashtra, India
}

\begin{abstract}
Electricity plays an important role in every aspect of life. Day by day as the digitalization is increasing the need of electricity is also increasing. Till now the production of electricity was totally dependent on conventional energy sources. But with increasing load demand these sources are getting exhausted rapidly. So, to reduce dependency on conventional energy sources we have already switched over to non-conventional energy sources which includes solar, wind, hydro, tidal etc. It is found that maximum electricity can be generated using solar energy. Various technologies are invented regarding the tracking of solar energies. Maximum power point tracking is the most popular technique among all which ensures the maximum use of solar energy to get converted into electricity. This paper represents one such method of MPPT i.e., Incremental conductance. The algorithm of incremental conductance with simulations result obtained in MATLAB is briefly discussed in this paper.
\end{abstract}

Keywords- MPPT, Incremental Conductance, Photovoltaic Power System

\section{INTRODUCTION}

In solar power technology, photovoltaic systems have been used since many years [1]. Today in comparison with other sources PV has become the most important source of power in various applications including the industries [4]. It is found to be the cleanest energy that can be used for generation of electricity. Also, many techniques have been developed for increasing efficiency of solar energy with reductions in cost. In solar photovoltaic systems the solar panels are used which converts the solar energy directly into the electricity. The output of the solar panel depends upon the solar radiations and also on the tracking system of the solar panel. Although solar radiations depend upon the environmental conditions, but we can improve the tracking system of PV system to increase the efficiency of solar panel [6].

It is observed that the V-I characteristics of the solar cell is non-linear and varies with change in solar radiations and temperature. The V-I and V-P characteristics of solar cell has the unique point called as Maximum power point, at this point the whole system i.e., the solar panel generates maximum power and works at higher efficiency. The MPP of solar cell is not known, but it can be found using some calculations and

\author{
Dr. Subhada Muley(Guide) \\ Department of EE \\ Priyadarshini College of Engg, \\ Nagpur, Maharashtra, India
}

algorithms. To implement these calculations and algorithms Maximum Power Point Tracking (MPPT) system has been introduced.

Photovoltaic is a system which converts solar radiation (sunlight) into electricity using semiconducting material which exhibits photovoltaic effect. The output of solar cell is DC which then can be converted into AC using inverters for the various applications. Fig. 1 shows the solar cell converting solar energy into electricity [2].

The standard equivalent circuit of the PV cell is shown in Fig.3.

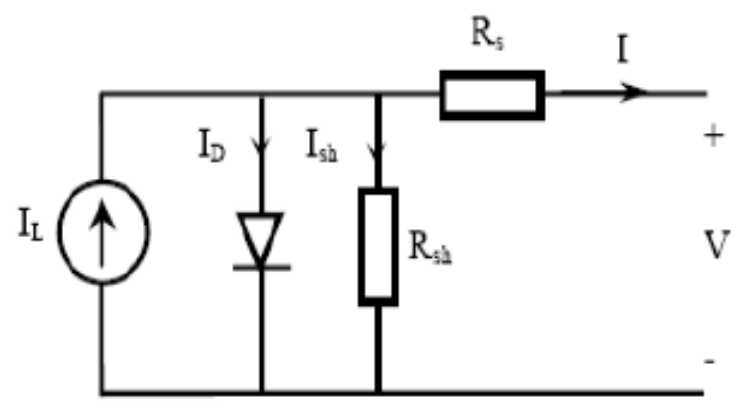

Fig 3. PV cell circuit

The basic equation that describes the I-V Characteristics of the $\mathrm{PV}$ model is given by the following equation:

$$
\text { I=Isc-Io (eq (V+I Rs) kT-1)-(V+I Rs Rp) }
$$

where,

I - current in solar PV cell (A)

$\mathrm{V}$ - voltage in solar PV cell (V)

$\mathrm{P}$ - power in solar PV cell (W)

Isc - short circuit current of solar PV cell (A)

Voc - open circuit voltage of the solar PV cell (V)

Io - reverse saturation current

$\mathrm{q}$ - electron charge, $\mathrm{q}=1.602 \times 10-19 \mathrm{I}$

$\mathrm{k}$ - Boltzmann's constant, $\mathrm{k}=1.381 \times 10-23(\mathrm{~J} / \mathrm{K})$

$\mathrm{T}$ - absolute temperature (K)

The rest of the paper is organized as follows. System configuration is discussed in section II Theory of incremental conductance is explained in section III. Proposed algorithm is given in section IV. Model of MPPT is shown in section V along with the simulation results. The remarks regarding the topic is concluded in the section VI. 


\section{International Journal of Engineering Applied Sciences and Technology, 2021 \\ Vol. 5, Issue 11, ISSN No. 2455-2143, Pages 192-196 \\ Published Online March 2021 in IJEAST (http://www.ijeast.com)}

\section{SYSTEM CONFIGURATION}

\section{MPPT}

MPPT or maximum power point tracking is the technique commonly used in solar systems to extract maximum power under all weather conditions. In this tracking no mechanical equipment is included. It is totally electronic based system. In this system various electronic components are used to track the MPP by varying the electrical parameters of the module. MPPT system mainly includes the charge controller which observes the output of the solar panel and compares it to the battery voltage and selects the best power that can be match the requirement of the battery or the utility grid. The proposed block diagram of MPPT is shown in fig 4.

Fig 4. Block of solar panel with MPPT

There are various MPPT methods developed till now such as

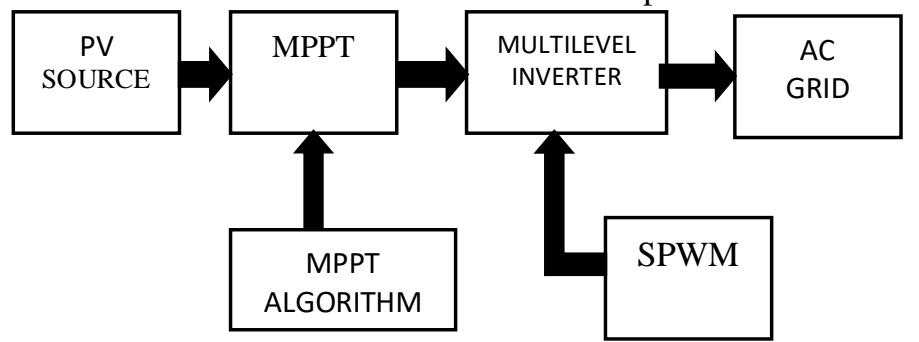

the perturbation and observation (P\&O) technique, the incremental conductance (IncCond) technique, ripple correlation technique, short circuit current (SCC) technique, and open circuit voltage (OCV) technique [10-11] . Earlier the perturb and observe method was most commonly preferred but it has various drawbacks. In this method due to rapid change in the environmental conditions the misjudgment phenomenon occurs due to which exact MPP is not achieved. This drawback can be overcome using the incremental conductance which is mainly discussed in this paper [7-9].

\section{INCREMENTAL CONDUCTANCE}

Overcoming the drawbacks of $\mathrm{P} \& \mathrm{O}$, this technique works at the maximum power point of the solar panel. The disturbance given to the parameter such as voltage and current is small enough to avoid the misjudgment phenomenon. It follows the algorithm to achieve the point of MPP by calculating the slope of $\mathrm{P}-\mathrm{V}$ characteristics. In this method the maximum power point is tracked by the MPPT and once it is tracked it stops perturbing and starts working at maximum MPP. This can be possible by calculating the relationships between $\mathrm{dI} / \mathrm{dV}$ and I/V. This relationship can be derived by calculating the slope of PV characteristics as follows: -

$$
\begin{aligned}
& \frac{d P}{d V}=\frac{d(V I)}{d V} \\
& \frac{d P}{d V}=I+\frac{d I}{d V} V
\end{aligned}
$$

At the MPP:

$$
\mathrm{dP} / \mathrm{dV}=0
$$

So:

$$
\frac{\mathrm{dI}}{\mathrm{dV}}=-\frac{\mathrm{I}}{\mathrm{V}}
$$

So to achieve the MPP above condition of eq. (1) has to be satisfied. This is shown in the algorithm of incremental conductance.

The above relation can be shown in the below graph:-

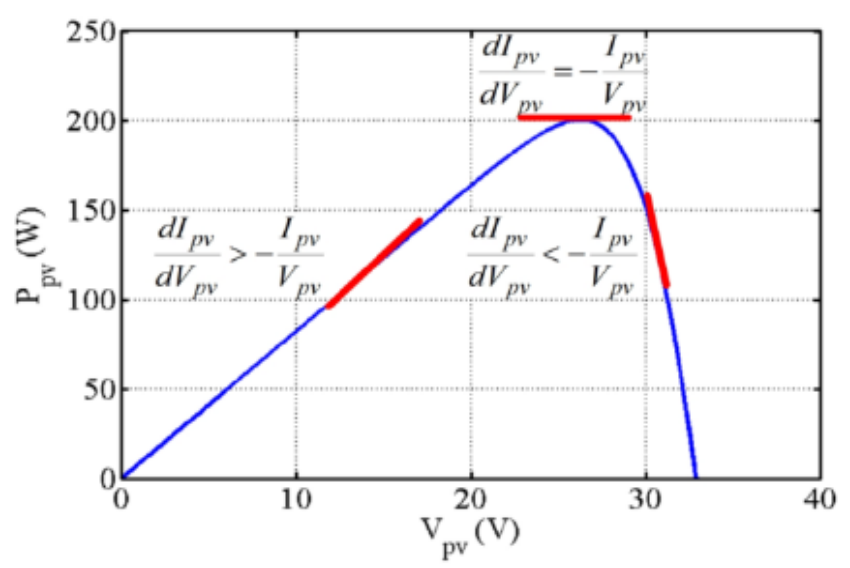

Fig 5. Graph of solar output with MPPT

From the above graph it is observed that at $\mathrm{dI} / \mathrm{dV}=-\mathrm{I} / \mathrm{V}$ the slope of graph is zero which is the maximum power point (MPP) whereas it is increasing at the left of MPP and decreasing at the right of MPP.

\section{PROPOSED ALGORITHM}

Algorithm of Incremental Conductance 


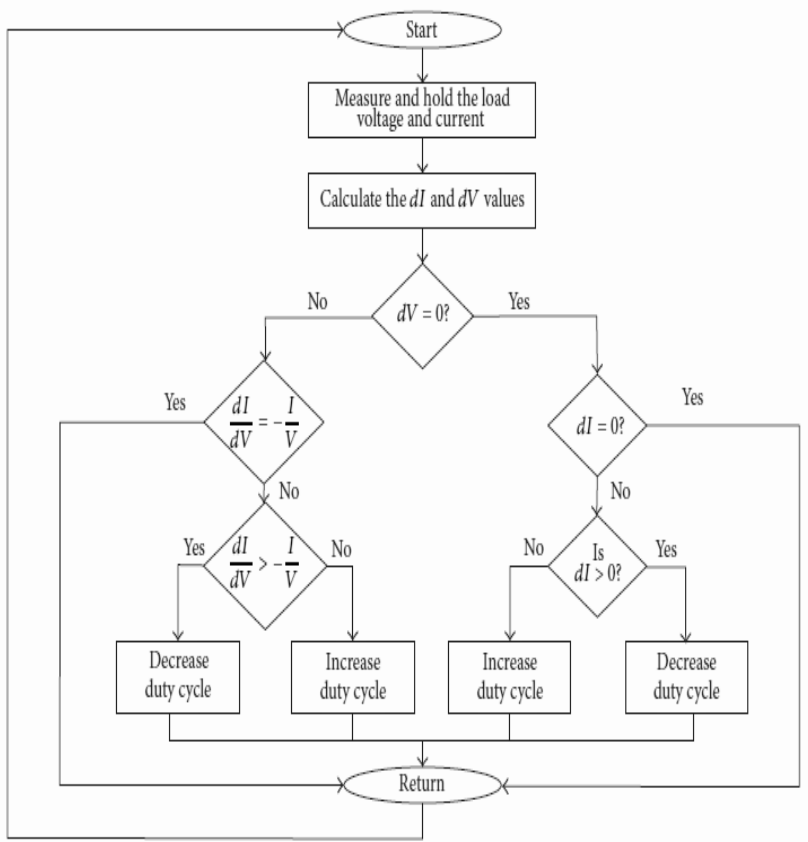

In this algorithm the value of voltage and current is measured and observed. Then the values of $\mathrm{di}$ and $\mathrm{dv}$ are calculated. These values are compared with the relationship obtained to satisfy the condition for MPP if it is satisfied then the MPP of the panel is tracked. If the condition is not satisfied then it is further compared with the reference values and as per the reference values the duty cycle of the MPPT is increased or decreased to obtain the MPP.

\section{EXPERIMENT AND RESULT}

The above algorithm has been successfully implemented in the MATLAB/SIMULINK. The model of the MPPT with incremental conductance is shown in fig 7. The simulation results of output of the PV module is shown in the following figures. Let us consider the solar panel with insolation $1000 \mathrm{w} / \mathrm{m} 2$ and temperature $50^{\circ} \mathrm{C}$ simulated in the MATLAB with and without MPPT circuit.

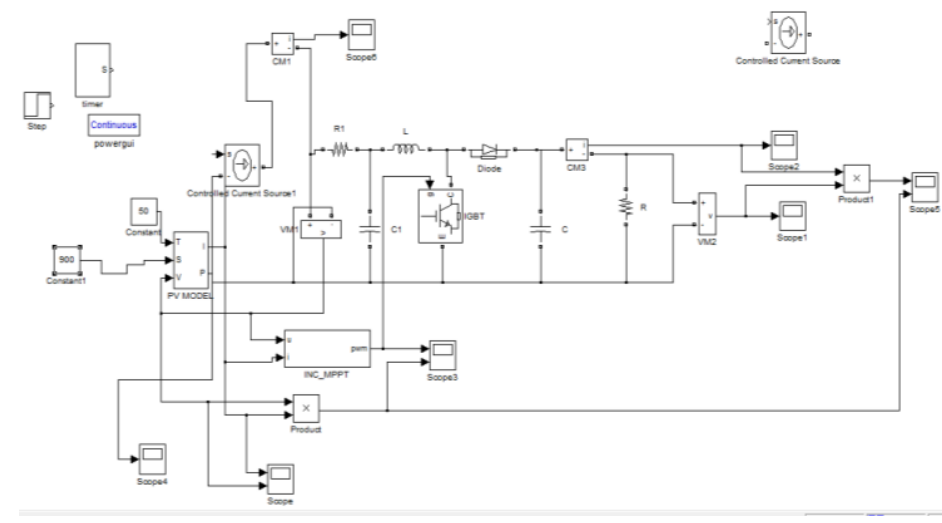

Fig 7. Simulation circuit of Matlab

SIMULATION RESULTS

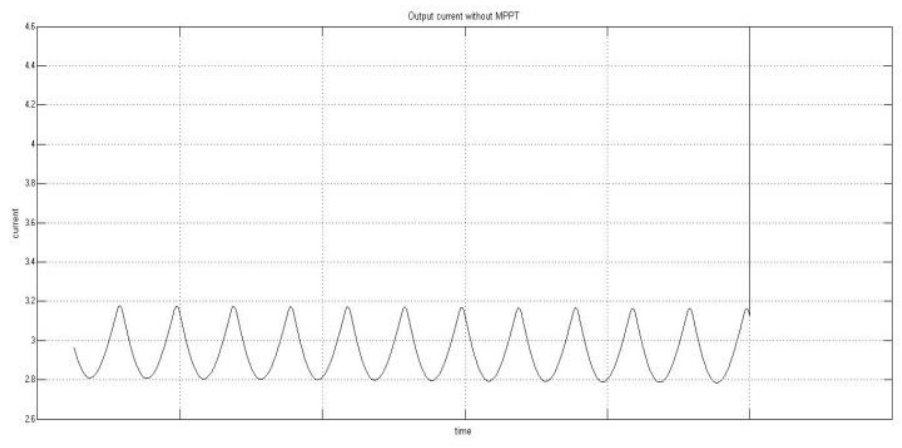

Fig 8. Output current of solar panel without MPPT

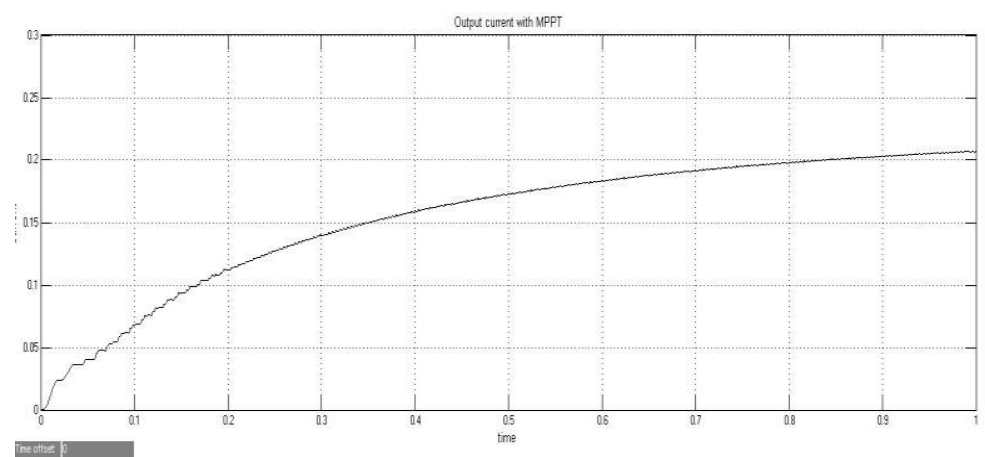

Fig 9. Output current of solar panel with MPPT 


\section{International Journal of Engineering Applied Sciences and Technology, 2021 \\ Vol. 5, Issue 11, ISSN No. 2455-2143, Pages 192-196 \\ Published Online March 2021 in IJEAST (http://www.ijeast.com)}

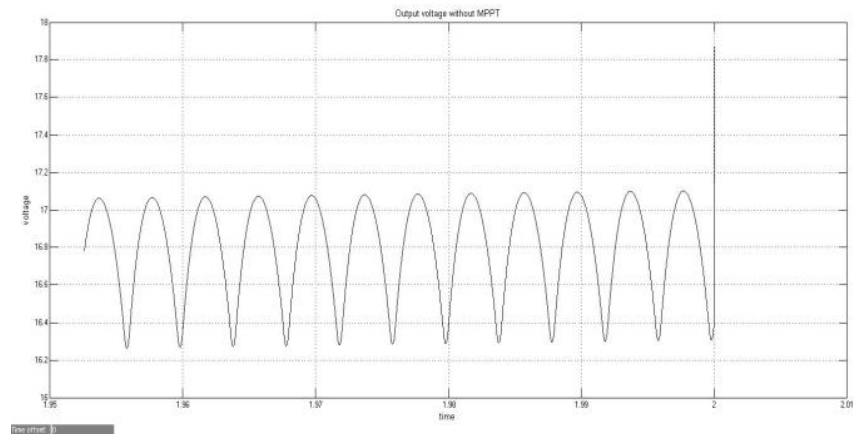

Fig 10. Output voltage of solar panel without MPPT

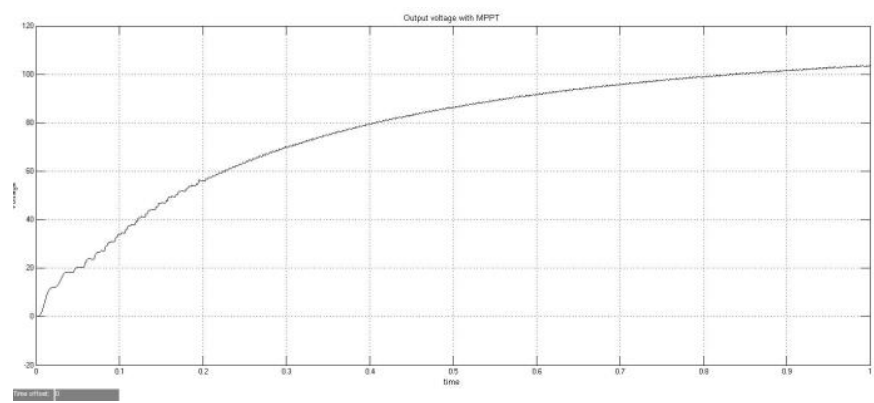

Fig 11. Output voltage of solar panel with MPPT

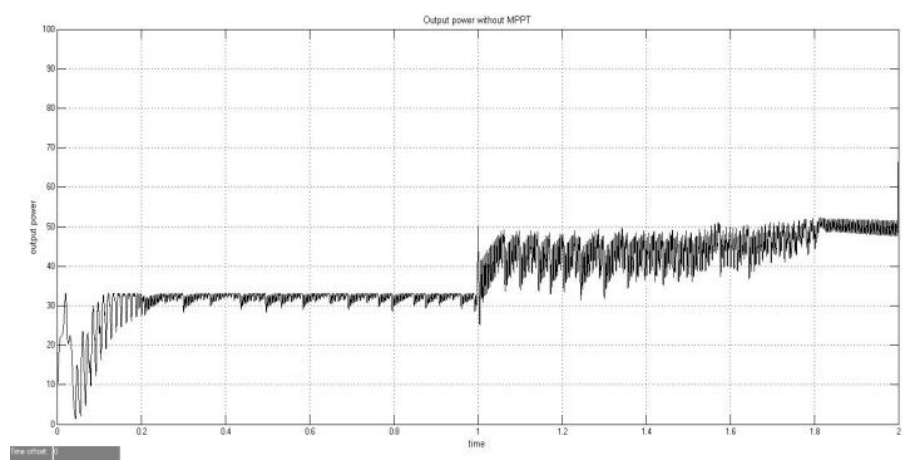

Fig 12. Output power of solar panel without MPPT

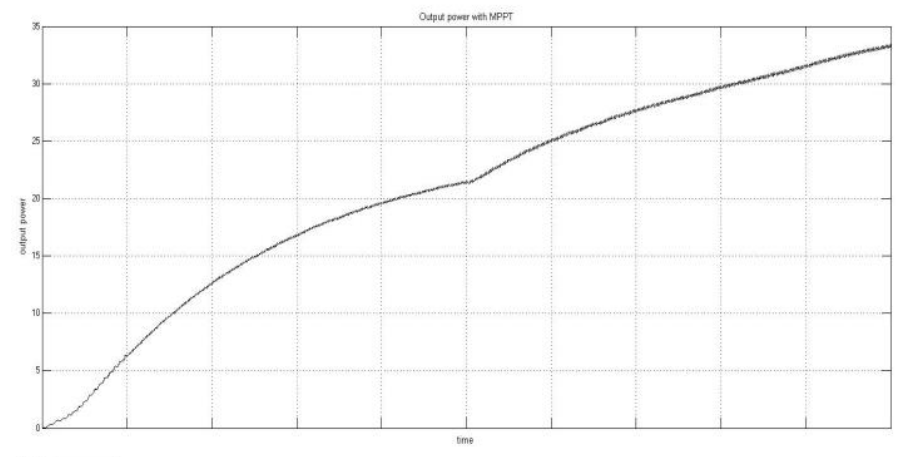

Fig 12. Output power of solar panel with MPPT

\section{CONCLUSION}

From the above simulations we can see that using the incremental conductance technique the MPP can be easily determined without much perturbations. Also the efficiency of overall system is increased with reduction in cost. With this method the system responds quickly to any changes in weather conditions. It continuously maintains the maximum power point and gives the maximum power output. It has successfully increased the tracking hours of the solar panel.

\section{REFERENCE}

1. Yu Ting-Chung and Lin Yu-Chenge. December 5, 2012. A Study on Maximum Power Point Tracking Algorithms for Photovoltaic Systems. Department of Electrical Engineering, Lunghwa University of Science Technology.

2. Chafle S. R., Vaidya U. B., June 2013. Incremental Conductance MPPT Technique for PV System IJAREEIE, Volume 2, Issue 6.

3. Abbes.H, Abid .H, Loukil.K, 2015. An Improved MPPT Incremental Conductance Algorithm Using T-S Fuzzy System For Photovoltaic Panel IJRER, Volume 5, No.1.

4. Christhoper.W and Dr. Ramesh.R., 2013. Comparative Study of P\&O and InC MPPT Algorithms, AJER, Volume 2, Issue-12, pp-402-408, 2013

5. Challa .D.R. and Raghavendar.I, Nov-Dec, 2012. Implementation Of Incremental Conductance MPPT With Direct Control Method Using Cuk Convertor, IJMER, Volume 2, Issue 6, pp-4491-4496

6. Pakkiraiah.B and Sukumar.G.Durga,2016. Research Survey on Various MPPT Performance Issues to Improve the Solar PV System Efficiency, Journal Of Solar Energy, Volume 2016

7. Vitilrao.P, Dr. Sudha.K.R, Devi .S.P, 2013. Incremental Conductance (IncCond) Algorithm For Maximum Power Operating Point (MPOP) Of Photovoltaic (PV) Power Generation System, AJER, Volume 2, Issue 12, pp-334-342

8. Dhaouadi GUIZA; Djamel OUNNAS; Youcef SOUFI; Salah CHENIKHE, 25 November 2019. Implementation of Incremental Conductance Based MPPT Algorithm for Photovoltaic System, IEEE.

9. Swanepoel Nathan Chris, Richards Coneth Graham, Okojie Daniel Esene, Ehlers Pieter Johannes, Nnachi Agha Francis, 2020. Experimental Investigation of Incremental 
Conductance-based MPPT for PV Arrays, PES/IAS

PowerAfrica 2020 IEEE, pp. 1-5

10. Mokhlis Mohcine, Ferfra Mohammed, Vall Hemeyine Ahmed, idrissi Rafika El, Ahmed Cheikhne Cheikh, Taouni Abderrahim,2020. Comparative Study Between the Different MPPT Techniques, Renewable Energies for Developing Countries (REDEC) 2020 5th International Conference on, pp. $1-6$

11. Swanepoel Nathan Chris, Richards Coneth Graham, Okojie Daniel Esene, Ehlers Pieter Johannes, Nnachi Agha Francis,2020. A comparative study of maximum power point tracking algorithms for PV arrays, Energy Conference (ENERGYCon) 2020 6th IEEE International, pp. 819-823, 2020

12. Liu .F, Duan .S, Liu.B., and Kang.Y, Jul. 2008 -A variable step size INC MPPT method for PV systems, „IEEE Trans. Ind. Electron., vol. 55,no. 7, pp. 2622-2628, Jul. 2008.

13. Elgendy M.A., Zahawi B., Atkinson D. J., "Assessment of Perturb and Observe MPPT Algorithm Implementation Techniques for PV Pumping Applications,' IEEE Transactions on Sustainable Energy,vol. 3, no. 1, pp. 21-33, 2012 